Gibson, T., Stirling, A. C., Keddie, R. M. \& Rosenberger, R. F. (1958). J. gen. Microbiol. 19, 112-129

\title{
Bacteriological Changes in Silage Made at Controlled Temperatures
}

\author{
By T. GIBSON, ANNA C. STIRLING, R. M. KEDDIE \\ AND R. F. ROSENBERGER \\ School of Agriculture, Edinburgh
}

SUMMARY: Silage made in the laboratory at $22^{\circ}, 30^{\circ}$ and $40^{\circ}$ from five specimens of grass was examined after $1,2,3$ and 8 days and 6 months. The dominant bacteria on fresh grass were obligate aerobes which died rapidly in a closed silo. Bacteria capable of anaerobic growth were represented irregularly and often weakly on grass. This can account for much of the variation in the composition of bacterial populations in silage. Organisms that developed extensively in much of the silage were the Klebsiella group, Lactobacillus, Streptococcus, Leuconostoc, Pediococcus, Clostridium and Bacillus. Each proceeded to multiply soon after silos were closed; all stopped growing at about the same time. The rate of growth and the concentration of viable organisms reached were determined by properties of the herbage. Gram-negative organisms were restrained at $40^{\circ}$, Clostridium and Bacillus at $\mathbf{2 2}^{\circ}$. The multiplication phase was short; it could be completed by the third day at all three temperatures. Cessation of growth could not be attributed to the accumulation of acids. Much acid was formed after all the main groups had reached the phase of decreasing viable count. When the lactic acid fermentation was not vigorous the decreases in $\mathbf{p H}$ value were most rapid at $40^{\circ}$ and slowest at $22^{\circ}$.

In the commonest methods of making silage the preservation of the herbage is known to rely in part on the formation of acids, chiefly lactic acid, by bacterial fermentation of plant sugars (Watson, 1939; Barnett, 1954). When sufficient acid is produced the material will be preserved, provided that oxygen is excluded. Inadequate concentrations of acid may allow an intense decomposition in which clostridia appear to be the chief causative agents; access of air permits the activity of aciduric aerobes. All the genera of lactic acid bacteria now recognized, Lactobacillus, Streptococcus, Leuconostoc and Pediococcus, have been demonstrated in silage. In many instances lactobacilli were found to be the dominant bacteria. Coliform organisms, Clostridium and Bacillus spp. have also been shown to multiply in much silage. Other bacterial groups and yeasts have been detected less often. Most investigators agree that in the early stages there is a multiplication of a mixture of organisms, including the coliform group, and that in well-preserved silage lactic acid bacteria, especially lactobacilli, become dominant. Apart from these features the literature indicates that there is much variation in the course of bacterial development.

In agricultural practice much importance is attributed to temperature as a factor influencing the silage fermentation, yet work on the relationship of temperature to the efficiency of preservation has yielded surprisingly contradictory results. It is therefore remarkable that little attention has been given 
to the effect of temperature on the bacterial populations, except indirectly by chemical analyses of their metabolic products. Among the few contributions on this problem are those of Burri (1918), Gerlach, Günther \& Seidel (1926) and Scheunert \& Schieblich (1926), who made observations on the types of bacteria which develop during the heating of silage. Their findings lack uniformity and allow of little generalization. The results of an experiment comparing the changes in viable bacterial count of silage made at $22^{\circ}, 30^{\circ}$, and $40^{\circ}$ were given by Stirling (1951).

The object of the work about to be described was to gain a clearer understanding of the bacterial ecology of silage. An attempt was made to follow the development of the several bacterial groups when the conditions were varied (1) by using specimens of rye-grass which differed in character and (2) by making the silage on each occasion at $22^{\circ}, 30^{\circ}$ and $40^{\circ}$. In order to control temperature the silage was prepared in the laboratory.

\section{METHODS}

Grass. The herbage used for ensilage was perennial rye-grass (Lolium perenne), either S 23 or S24. The grass was grown as pure strains on small plots. Particulars of the specimens employed are shown in Table 1. In all manipulations of the grass it was not allowed to come in contact with unsterile surfaces. The harvesters wore sterile rubber gloves and cut the grass with sterile sheep shears. The herbage was collected in bags, and without delay taken to the laboratory where it was cut into short lengths $(1-3 \mathrm{~cm}$.) and thoroughly mixed.

Table 1. The perennial rye-grass used for ensilage

\begin{tabular}{|c|c|c|c|c|}
\hline $\begin{array}{l}\text { Experi- } \\
\text { ment }\end{array}$ & Type of grass & $\begin{array}{l}\text { Date of } \\
\text { cutting }\end{array}$ & $\begin{array}{c}\text { Dry matter } \\
(\%)\end{array}$ & $\begin{array}{l}\text { Crude protein* } \\
\text { (\% of dry } \\
\text { matter) }\end{array}$ \\
\hline 7 & $\begin{array}{l}\text { S 24, spring growth, } \\
\text { mainly leaf, first cut }\end{array}$ & 22 May & $21 \cdot 1$ & 14 \\
\hline 8 & $\begin{array}{l}\text { S24, preflowering, first } \\
\text { cut }\end{array}$ & 12 June & $21 \cdot 4$ & $8 \cdot 1$ \\
\hline $\mathbf{9}$ & $\begin{array}{l}\text { S24, stemmy, second } \\
\text { cut }\end{array}$ & 20 Aug. & $25 \cdot 6$ & $9 \cdot 0$ \\
\hline 10 & $\begin{array}{l}\text { S23, summer-sown, } \\
\text { first cut }\end{array}$ & 28 Aug. & $21 \cdot 0$ & $10 \cdot 8$ \\
\hline 15 & $\begin{array}{l}\text { S 24, spring growth, } \\
\text { mainly leaf, first cut }\end{array}$ & 9 June & $20 \cdot 2$ & $21 \cdot 4$ \\
\hline
\end{tabular}

Ensilage. Pyrex glass tubes $c .20 \times 3 \mathrm{~cm}$. were filled each with $50 \mathrm{~g}$. grass. Using a wooden rod of a diameter slightly less than that of the tube the grass was packed as evenly as possible. Each tube was closed with a rubber stopper carrying a valve of mercury supported on a sintered glass disk, which permitted the escape of gases but prevented the entry of air. Before use the stoppers were sterilized over formalin in a desiccator. A set of filled tubes was 
placed, in the dark, in each of three water baths controlled at $22^{\circ}, 30^{\circ}$ and $40^{\circ}$.

Preparation of grass and silage for examination. A sample (50 g.) of the fresh grass, taken after chopping and mixing, was placed in a tared macerator jar. Sterile water was added until the suspension weighed $300 \mathrm{~g}$. The material was then disintegrated for $2 \mathrm{~min}$. by an electric top-drive macerator. In the case of silage all the material was withdrawn from a tube by a sterile corkscrew with an elongated shank and treated in the same way as the grass. The macerate was used for the bacteriological examinations and for the electrometric determination of $\mathrm{pH}$ value.

The macerator was washed thoroughly between each examination and sterilized by swabbing with ethanol and flaming. The rubber pad surrounding the spindle was difficult to sterilize; it was covered before each maceration with a sterile disk of rubber sheeting slotted at the centre so that it fitted closely round the spindle. Sterility tests, which were carried out regularly by running the macerator with $300 \mathrm{~g}$. sterile water and then plating $1 \mathrm{ml}$. of the water on each of several media, rarely yielded more than an occasional colony when these precautions were taken.

\section{Bacteriological media and methods}

Serial decimal dilutions of the macerate were made in sterile tap water and were used for the inoculation of five media which yielded counts of different bacterial groups. The media and their uses are described below.

Medium (1). Glucose yeast agar : peptone (Evans), 1 g.; meat extract (Lemco), 1 g.; yeast autolysate, $5 \mathrm{ml}$; glucose, 0.5 g.; agar (Davis), 1.5 g.; tap water, $100 \mathrm{ml}$.; pH 6; sterilized momentarily up to $22 \mathrm{lb}$./sq.in. To prepare the yeast autolysate, $1 \mathrm{~kg}$. brewer's yeast in 11 . water was held at $50^{\circ}$ for $24 \mathrm{hr}$.; after centrifugation, the supernatant fluid was sterilized in bottles momentarily at $22 \mathrm{lb} . / \mathrm{sq} . \mathrm{in}$.

Poured plates were incubated in air for 5 days at $30^{\circ}$. The medium might be expected to support the growth of most of the silage organisms other than the obligate anaerobes.

Medium (2). Acetate agar (Keddie, 1951): peptone (Evans), 1 g.; meat extract (Lemco), 1 g.; yeast autolysate (as in medium 1), 5 ml.; tomato extract, $20 \mathrm{ml}$.; glucose, $1 \mathrm{~g}$; ; Tween 80, 0.05 ml.; agar (Davis), 1.5 g.; tap water, $100 \mathrm{ml}$. The peptone, meat extract and agar were dissolved together, the yeast autolysate and tomato extract then added and the $\mathrm{pH}$ value adjusted to $5 \cdot 4$; after filtration the glucose and Tween 80 were added, and the medium bottled and sterilized at $15 \mathrm{lb}$./sq.in. for $15 \mathrm{~min}$. To prepare the tomato extract, $1 \mathrm{~kg}$. tomatoes $+450 \mathrm{ml}$. water were steamed for $30 \mathrm{~min}$.; the pulp was then squeezed through muslin.

Just before pouring plates, $10 \mathrm{ml}$. of $2 \mathrm{M}$-acetic acid/sodium acetate buffer of $\mathrm{pH} 5.4$ were added to $90 \mathrm{ml}$. of molten medium. The final $\mathrm{pH}$ should be $5 \cdot 4 \pm 0 \cdot 05$. After the inoculated agar had solidified a second layer of the acetate agar was added. Plates were incubated in air for 5 days at $30^{\circ}$. They were used for the enumeration of lactobacilli. For this purpose it was essential to 
identify colonies of Lactobacillus by isolation and microscopical examination of the isolates, since Leuconostoc and Pedicoccus are capable of growth on the medium.

Medium (3). Lactate agar: ammonium lactate syrup (c. 61\%), $1 \mathrm{ml}$; glucose, 0.2 g.; L-glutamic acid, 0.2 g., $\mathrm{K}_{2} \mathrm{HPO}_{4}, 0 \cdot 1$ g.; $\mathrm{MgSO}_{4} .7 \mathrm{H}_{2} \mathrm{O}, 0.02$ g.; washed shred agar, $1.5 \mathrm{~g}$; ; tap water, $100 \mathrm{ml}$.; pH 6; sterilized momentarily at $22 \mathrm{lb} . / \mathrm{sq}$.in. Just before use crystal violet was added to a final concentration of 1/500,000 in order to inhibit Gram-positive organisms. On plates incubated for 3 days at $30^{\circ}$ a count is made of Gram-negative bacteria.

Medium (4). Medium for lactate-fermenting anaerobes (Rosenberger, 1951): sodium lactate syrup (c. $70 \%$ ), $1.5 \mathrm{ml}$; sodium acetate, hydrated, $0.8 \mathrm{~g}$.; $\left(\mathrm{NH}_{4}\right)_{2} \mathrm{SO}_{4}, 0.05$ g.; yeast autolysate (as in medium 1), $3 \mathrm{ml}$.; biotin, $0.01 \mu \mathrm{g}$.; $p$-aminobenzoic acid, $10 \mu \mathrm{g}$; L-cysteine hydrochloride, $0.05 \mathrm{~g}$; thioglycollic (mercaptoacetic) acid, $0.05 \mathrm{ml}$; a mineral supplement; resazurin, $0.5 \mathrm{mg}$; agar, 0.2 g.; tap water, $100 \mathrm{ml}$.; $\mathrm{pH} 6$; sterilized momentarily at $22 \mathrm{lb}$./sq.in. The agar was dissolved before adding the other ingredients.

Medium (5). Medium for proteolytic anaerobes (Rosenberger, 1951): peptone (Evans), 1.5 g.; gelatin, 12 g.; yeast autolysate (as in medium 1), $1 \mathrm{ml}$; L-cysteine hydrochloride, 0.05 g.; resazurin, $0.5 \mathrm{mg}$.; tap water, $100 \mathrm{ml}$.; pH 7; sterilized momentarily at $22 \mathrm{lb}$./sq.in.

Before inoculation of media (4) and (5) the tubes were placed in boiling water for $10 \mathrm{~min}$. and then cooled to $45^{\circ}$. The inoculum was planted into the depths of the medium; the introduction of air and mixing was avoided. After inoculation the tubes were chilled to solidify the agar or gelatin. The medium was then covered to a depth of $3 \mathrm{~cm}$. with a seal of: agar, $1 \mathrm{~g}$.; L-cysteine hydrochloride, $0.05 \mathrm{~g}$.; thioglycollic acid, $0.05 \mathrm{ml}$; resazurin, $0.5 \mathrm{mg}$.; tap

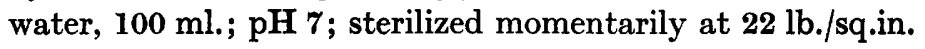

The cultures were incubated in air for 7 days at $30^{\circ}$ or $37^{\circ}$. In the first experiments $37^{\circ}$ was used; as a precaution $30^{\circ}$ was adopted. Up to now there have been no indications of different results at the two temperatures. The incubated cultures were examined as follows.

(a) Lactate fermentation in medium (4) was recognized by gas formation, sufficient to raise the seal at least $2 \mathrm{~cm}$., and by an increase in $\mathrm{pH}$ value. To detect changes in $\mathrm{pH}$ value some of the culture was withdrawn and tested with bromothymol blue on a spot-plate.

(b) Protein breakdown in medium (5) was shown by gelatin liquefaction and by strong reactions for $\mathbf{N H}_{3}$ and $\mathrm{H}_{2} \mathrm{~S}$ in spot tests with Nessler's reagent and lead acetate. A vanillin spot-test (Roessler \& McClung, 1943) assisted the recognition of Clostridium sporogenes. Some, but apparently not all, of these reactions may be produced by non-proteolytic clostridia and by certain other bacteria (Rosenberger, 1956).

Dilutions of the silage macerate were inoculated into media (4) and (5) in triplicate, and the most probable numbers of each type of anaerobe were estimated by using the table of Hoskins (1934). 


\section{RESULTS \\ The bacterial populations of the fresh grass}

The data in Table 2 show that the bacterial populations on the specimens of grass varied considerably. In all cases the dominant organisms were strict aerobes. Many were Gram-positive and coryneform. The Gram-negative aerobes were in part pseudomonads, some of which were fluorescent, and in

Table 2. Bacterial populations of the fresh grass

\begin{tabular}{|c|c|c|c|c|}
\hline \multirow{3}{*}{ Experiment } & \multicolumn{4}{|c|}{ Counting medium used } \\
\hline & Glucose yeast agar & Lactate agar & Acetate agar & $\begin{array}{l}\text { Media for } \\
\text { anaerobes }\end{array}$ \\
\hline & \multicolumn{4}{|c|}{ Count/g. dry-wt. grass } \\
\hline 7 & $9,000,000$ & $2,100,000$ & $<25$ & $<\mathbf{1 7 0}$ \\
\hline 8 & $61,000,000$ & $1,500,000$ & $<\mathbf{2 5}$ & $<\mathbf{1 7}$ \\
\hline 9 & $220,000,000$ & $170,000,000$ & 22 & 2000 \\
\hline 10 & $35,000,000$ & $110,000,000$ & 5000 & 50 \\
\hline 15 & $\mathbf{2 , 6 0 0 , 0 0 0}$ & $<100,000$ & 29 & 2000 \\
\hline
\end{tabular}

part non-motile forms. The majority of the aerobic organisms formed colonies which were some shade of yellow. Bacteria capable of anaerobic growth, which have greater significance in relation to silage, were much less numerous on the fresh grass. Among the Gram-negative organisms estimated on lactate agar, facultative anaerobes of two kinds were detected as minorities. They were (a) a diverse group possessing the general characters of Klebsiella, and (b) the organism which has most frequently been named Bacterium herbicola (reviewed by Mack, 1936). Lactobacilli, as shown by the counts on acetate agar, were extremely scarce except in Expt. 10; in two cases this group was not demonstrated in $\mathbf{1 ~ m l}$. of undiluted grass macerate. The counts of clostridia were little higher; the species isolated were Clostridium butyricum, $C$. welchii (C. perfringens) and $C$. bifermentans. Aerobic spore formers were likewise scarce and did not occur in the macerate at dilutions greater than 1/10. Bacillus licheniformis was isolated from every specimen of grass; B. subtilis, B. pumilus and $\boldsymbol{B}$. circulans were encountered less often. The methods employed, although they did not afford counts of lactic acid cocci, were sufficient to prove that these organisms were rare. In some cases streptococci were detected by means of selective methods in $1 \mathrm{ml}$. of undiluted macerate.

The literature on the bacteria which occur on the aerial parts of growing plants is extensive but much of it is restricted in scope. It is of immediate interest that in work with several crops, results similar to those just described have been reported: for aerobes and coliform organisms by Kroulik, Burkey \& Wiseman (1955); for clostridia by Scheunert \& Schieblich(1926), Ruschmann \& Harder (1931), Allen \& Harrison (1937) and Nilsson \& Nilsson (1956); for lactic acid bacteria by Ruschmann \& Koch (1930), Stirling (1953), Kroulik, Burkey $\&$ Wiseman (1955) and Nilsson \& Nilsson (1956). The counts of lactobacilli 
reported by Allen, Harrison, Watson \& Ferguson (1937) and of lactic acid bacteria by Arnaudi (1940) are so high in comparison with all the other findings as to indicate that they were not obtained on freshly harvested herbage.

\section{Changes in the total viable count after ensilage}

The aerobic and anaerobic counts made in the silage have been combined to give total viable counts which are shown in Fig. 1. In Expt. 8 the results were incomplete for the silage held at $30^{\circ}$ for 2 days and at all three temperatures
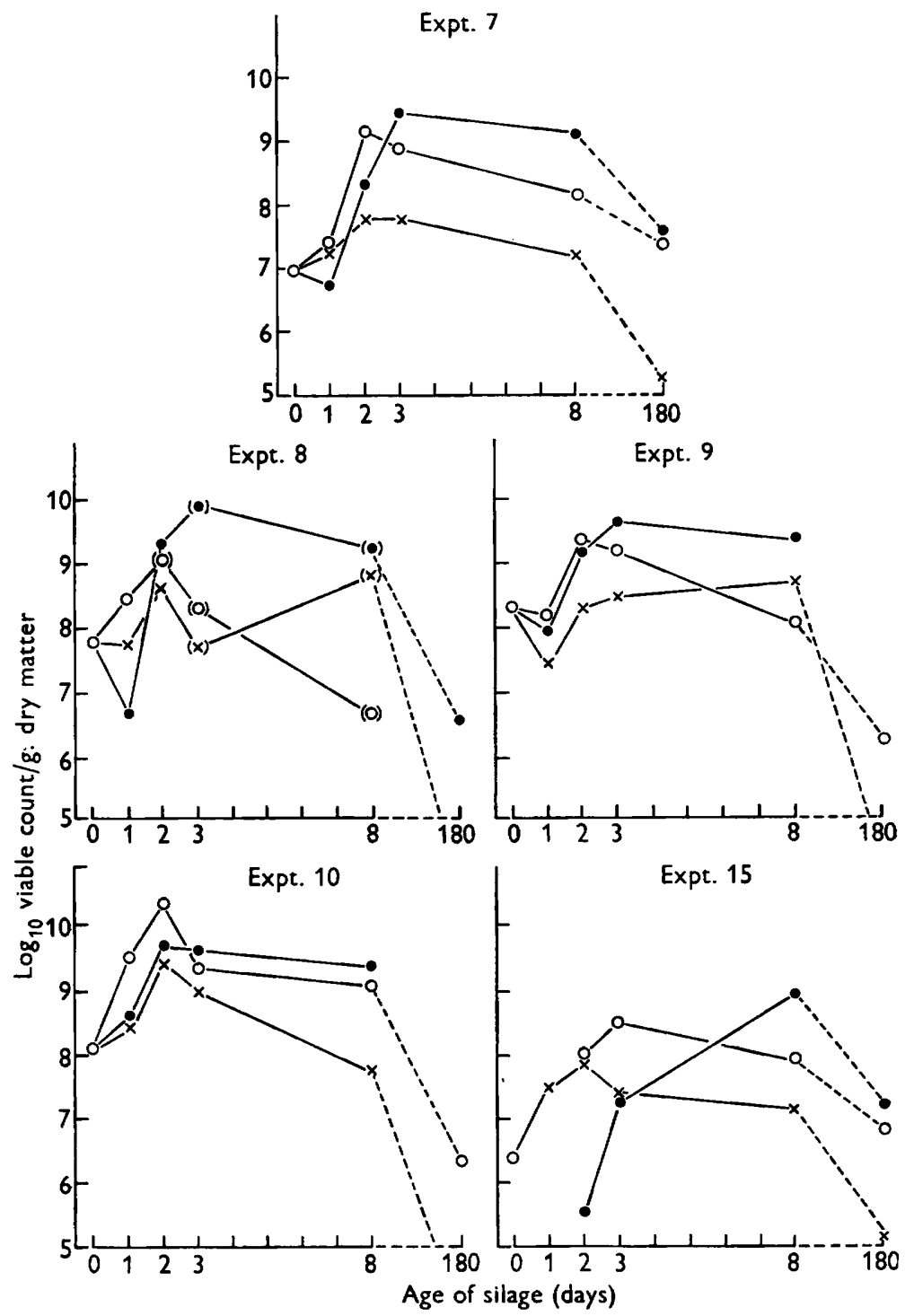

Fig. 1. Counts of total viable bacteria in silage. Silage made at $22^{\circ}, \bullet-0 ; 30^{\circ}, 0-0$; $40^{\circ}, x-x$. Incomplete count, -()$-$. 
for 3 and 8 days. In these instances faulty batches of media (4) and (5) were used, and the counts shown in Fig. 1 either do not include any anaerobes or do not include lactate-fermenting anaerobes. The figures for the 180-day examination of the $30^{\circ}$ silage in Expt. 8 and for the $22^{\circ}$ silage in Expts. 9 and 10 have been omitted as in each case air had entered the tube, mould had developed, and the viable counts were much higher than in anaerobic silage. In Expt. 15 growth was unexpectedly slow, and the dilutions examined on the first day were not all sufficiently small to afford complete results.

When living herbage is packed in a container which excludes air the oxygen is quickly consumed and replaced by $\mathrm{CO}_{2}$. The efficiency of the method of cultivating obligate anaerobes which utilizes this action (McClung, McCoy \& Fred, 1935) shows how rapidly will the process be completed when the gas space is small. In the laboratory silage this change was accompanied by a rapid disappearance of the aerobic bacteria of the herbage. At the same time several types of bacteria which are equipped for anaerobic growth proceeded to multiply rapidly. Those that did so had been minorities, frequently very small minorities, in the bacterial populations of the fresh herbage. The net result was that the viable count could for a period show a decrease from the original value. Several examples of this may be seen in Fig. 1. The graphs show that the rate of growth and the maximum density of the viable populations varied with the herbage and with the temperature. It might be expected that the results were influenced in some measure by the variation, to be discussed presently, in the types of bacteria which developed. The multiplication phase was frequently of short duration. In Expt. 10 it was completed by the third day even at the lowest of the three temperatures. It is evident that a count of bacteria after 6 months-i.e. when a field silo might be openedgives little information concerning the course of the bacterial development.

\section{The bacteria that multiplied in the silage}

An attempt was made to fractionate the complex populations which developed in all the silage. A primary division was made into four fractions, and the results are shown in Table 3. Additional details are given in the following discussion.

Gram-negative organisms. The lactate agar (medium 3), used for the estimation of these organisms, was sufficiently selective for the purpose. Grampositive bacteria could develop on the low-dilution plates required in the examination of aged silage and also in the vicinity of colonies of Gram-negative rods, but they were usually recognized without difficulty.

With the exception of a few examinations the dominant Gram-negative organisms in the silage were indentified with the Klebsiella group. On the lactate agar they formed mucoid unpigmented colonies. They showed variations in their action on lactose (acid and gas, acid only, delayed fermentation and no change, in tests at $30^{\circ}$ ), glucose (acid and gas or acid only), gelatin and casein, and in their ability to grow at $37^{\circ}$. These variations did not appear to be correlated. Organisms which show a delayed fermentation of lactose are possibly responsible in part for the erratic and indefinite nature of the results obtained 


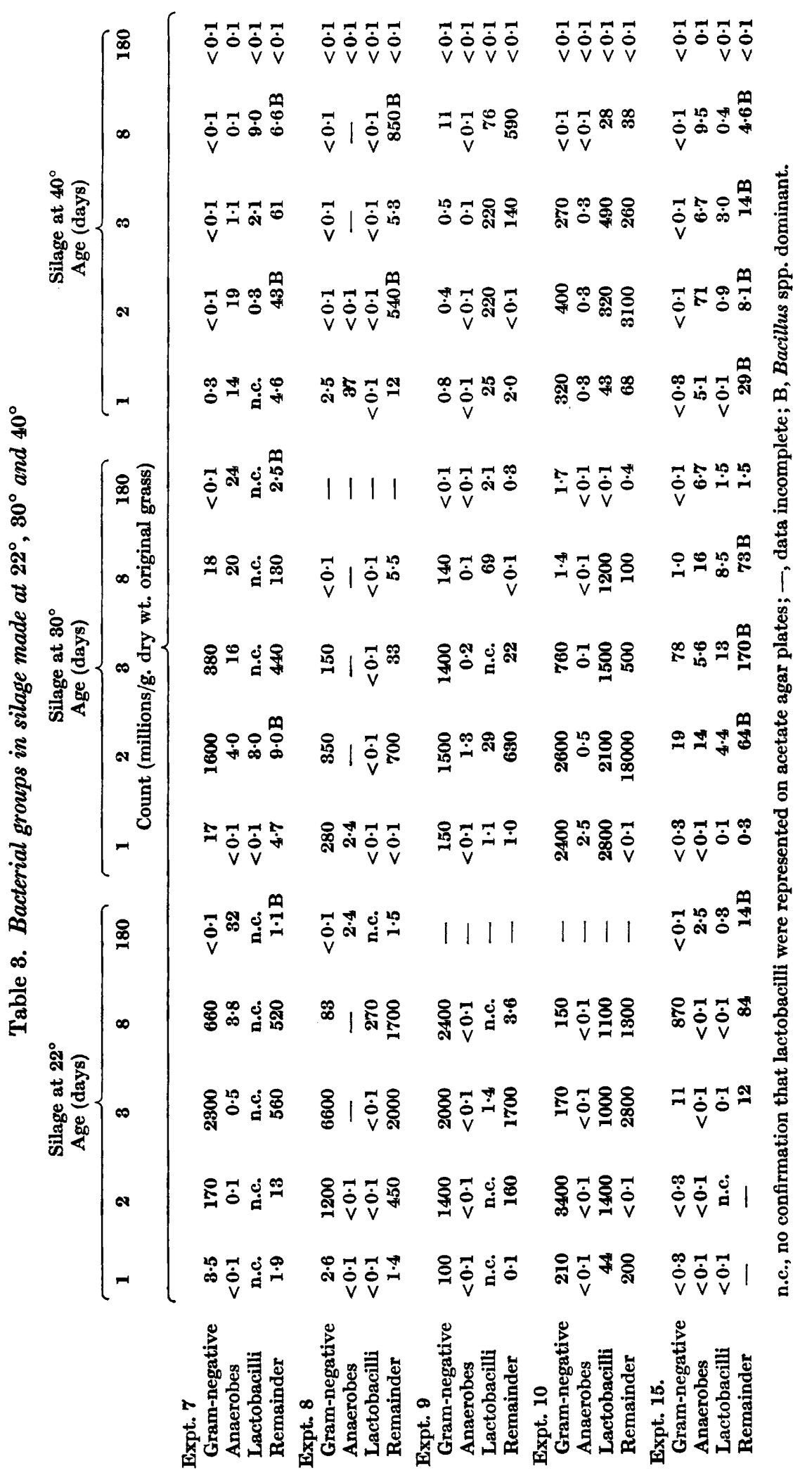


when the dilution method of counting, using liquid lactose media, is applied to silage. Escherichia coli was detected on three occasions only, all in Expt. 10, and at no time did it comprise more than $10 \%$ of the Gram-negative population. Bacterium herbicola occurred commonly, but it rarely represented more than $10 \%$ of all the Gram-negative rods in the silage. On lactate agar its colonies are distinguishable by their yellow colour. One other organism having yellow colonies was detected infrequently. It differs from $B$. herbicola in forming acid from lactose, in producing indole and in other properties.

During the phase of active growth the Gram-negative organisms dominated the bacterial populations, in terms of plate count, when the silage temperature was $22^{\circ}$ and in three cases when it was $30^{\circ}$. In the silage at $40^{\circ}$ they competed less effectively with other groups, a result which may be related to the finding that the maximum temperature for some strains is below $37^{\circ}$. Generally, the Gram-negative rods were the first of the main bacterial groups to show loss of viability after active multiplication stopped. One anomalous result was their presence in Expt. 10 after 6 months at $30^{\circ}$, when lactic acid bacteria had disappeared and the $\mathrm{pH}$ value had reached $4 \cdot 2$. The isolates in this case were recognized as belonging to a species which was not normally detected but they were not properly characterized. They were shown to be strict aerobes. Hence it is thought that they probably represented survivors of the original grass population rather than organisms which had multiplied in the silage.

Anaerobes. In most examinations the dominant species were either lactate fermenters or actively proteolytic. With the exception of the lactate-fermenting, Gram-negative coccus Veillonella gazogenes, which was isolated from silage made at $40^{\circ}$, all the anaerobes detected in these experiments were clostridia. Of the lactate-fermenting clostridia, Clostridium butyricum and an organism similar to $C$. paraputrificum (atypical in lacking motility and in some fermentation tests) were capable of active multiplication in the first $24 \mathrm{hr}$. at $40^{\circ}$. The latter organism was no longer detectable on the eighth day in the silage at any temperature. The actively proteolytic species were C. bifermentans, which multiplied in the first $24 \mathrm{hr}$. at $40^{\circ}$, and C. sporogenes, which tended to appear more slowly. Of these, only $C$. sporogenes was found at 6 months. Other species of clostridia were shown to have multiplied in single experiments. They are $C$. tetanomorphum, which ferments lactate but fails to grow satisfactorily in the selective lactate-acetate medium, and two species which are inactive towards lactate, $C$. welchii (C. perfringens) and C. sphenoides. These organisms were demonstrated by means of the gelatin medium in cases where they were not outnumbered by the actively proteolytic species.

The temperature of the silage was not found to determine the species of clostridia which developed, and neither the lactate-fermenting nor the actively proteolytic group consistently outnumbered the other at any of the three temperatures used. For these reasons the counts derived from media (4) and (5) have been combined to give total counts of anaerobes; these are set out in Table 3. The regular application of confirmatory tests excludes the possibility of a single organism having been responsible for a simultaneous count in both 
media. The results show that the main effects of temperature on the anaerobes were (1) at $22^{\circ}$ the lag phase was long and the growth slow, (2) at $40^{\circ}$ growth usually started immediately and the phase of decline set in early.

This work has been sufficient to indicate that the conditions which control spore germination, growth and spore formation of clostridia in silage are distinctly intricate. In addition, it has been shown that an examination of aged silage may give no information about the growth of these organisms at an earlier period. This last conclusion is in essential agreement with the findings of work in which the butyric acid content of mature silage was compared with its clostridial count (Ruschmann \& Harder, 1931; Kreula, 1955; Nilsson, Nilsson \& Abrahamson, 1956).

Lactobacilli. The data for this group were derived from the acetate agar plates. Other silage organisms that develop on the medium are Leuconostoc and Pediococcus; on rare occasions yeasts have appeared. To permit the recognition of lactobacilli isolations were made from a sample of the colonies on a suitable plate. The counts of lactobacilli shown in Table 3 are based on the proportionate representation of these organisms among the isolates. Where none of the colonies was that of a lactobacillus no figure is given in the table. The data are subject to large errors yet they do provide information on a bacterial group which is believed to have a special influence on the silage fermentation.

The pure cultures of lactobacilli were examined in varying degrees of detail. Of the homofermentative isolates that were extensively characterized, most were identified as Lactobacillus plantarum and $L$. acidophilus. Less frequently isolated were $L$. casei and other groups which do not appear to have been clearly defined by previous work. L. plantarum was encountered much less regularly than would be expected on the basis of the information in the literature (Allen \& Harrison, 1936; Allen et al. 1937; van Beynum \& Pette, 1939; Arnaudi, 1940; Orla-Jensen, Orla-Jensen \& Kjaer, 1947; OrlaJensen, 1947). . Few of the strains identified as $L$. plantarum were completely typical of that species. Heterofermentative strains represented a notable proportion of all the lactobacilli isolated. They were detected in the silage made at each of the three temperatures and at all stages in the fermentation. Of 159 strains of lactobacilli, to which a test for gas formation was applied, 56 were found to be heterofermentative. The majority of those examined in detail resembled most closely $L$. fermenti and L. buchneri. The strains attached to the latter species were atypical chiefly in failing to ferment melezitose.

In the present work a regular development of lactobacilli occurred solely in Expt. 10. Most of the silage made in Expt. 8 is believed to have been completely devoid of that group. The effects of temperature on the organisms seem to have depended in part on the species with which the grass happened to be seeded. Most of the strains of lactobacilli isolated in Expt. 9 were found to be capable of growth at $45^{\circ}$, and in that instance the best development occurred in the silage at $40^{\circ}$. The findings in Expt. 10 show that when the conditions in silage are favourable, the rate of multiplication of lactobacilli 
at $30^{\circ}$ can equal that of the other bacteria. In none of the experiments did lactobacilli show a definite competitive superiority during the phase of active growth. When the populations were declining lactobacilli retained their viability longer than most of the other organisms, although not as decisively as might have been anticipated. In Expt. 15, the silage at $30^{\circ}$ after 6 months gave approximately equal counts of pediococci and lactobacilli.

Remainder. This fraction shown in Table 3 was obtained by subtracting the sum of the Gram-negative bacteria and lactobacilli from the count on glucose yeast agar, the latter being taken as approximating to a count of all bacteria other than the anaerobes. Organisms which contributed to the figures are those for which selective methods of culture were not used. Streptococcus, Leuconostoc, Pediococcus and Bacillus are the groups which showed multiplication to a significant extent. Other groups did occur in the silage. For example, low numbers of micrococci and yeasts were occasionally detected. Where the Remainder consisted largely of Bacillus (shown by $\mathbf{B}$ in Table $\mathbf{3}$ ) the figure gives a valid indication of the occurrence of that group. As estimates of the cocci the figures must be regarded as unreliable in those cases in which the Gram-negative organisms or the lactobacilli had reached the phase of decline in silage made at $22^{\circ}$ or $30^{\circ}$, and also where these organisms were still giving some evidence of growth in the silage at $40^{\circ}$. In such circumstances the count of either group could be higher on glucose yeast agar then on the selective medium on which the group was enumerated, thus giving rise to a fictitious remainder. A similar variation in requirements for growth, associated with exposure of bacteria to adverse conditions, has frequently been recorded in the literature.

A large proportion of the streptococci appeared to be Streptococcus faecium Orla-Jensen or closely related organism. S. faecalis Andrewes \& Horder and its varieties were isolated less frequently. Leuconostoc and Pediococcus formed well-developed colonies on acetate agar, but the validity of the counts so obtained is unknown. Acetate agar has not yet been tested for capacity to give maximum viable counts of these groups. Leuconostoc gave little evidence of growth at $40^{\circ}$, but multiplied actively in the silage at the lower temperatures. The other coccal forms developed at all three temperatures.

Bacillus was inactive at $22^{\circ}$; at $40^{\circ}$ it formed a larger proportion of the whole bacterial population than it did at $30^{\circ}$. In Expts. 8 and 15 Bacillus licheniformis became the dominant organism at $40^{\circ}$. Its development in these cases resembled that shown by the Gram-negative rods in most of the silage made at $\mathbf{2 2}^{\circ}$, thus suggesting that the two groups may be alternates which are selected by the ambient conditions. $B$. coagulans was demonstrated in all experiments at $40^{\circ}$. The counts of this organism showed little indication of decrease at the 8-day examinations, thus indicating that its powers of survival were similar to those of the non-sporing lactic acid bacteria. B. polymyxa multiplied in the two materials richest in nitrogen (Expts. 7 and 15). In these it was prominent after 6 months at $22^{\circ}$ and $30^{\circ}$, an indication that it is capable of spore formation in silage. 


\section{Variations in the composition of the bacterial populations}

The analyses of the populations given in Table 3 and discussed above provide information about the inter-group competition. They show that bacteria of all the main groups which were found to increase in the silage were capable of proliferation during the phase of general multiplication when the temperature was appropriate for the organism. The observation that Lactobacillus and Clostridium spp. may develop as early and as rapidly as other organisms demonstrates that fresh herbage deprived of oxygen provides conditions suitable for some of the more fastidious types of bacteria. There was a tendency when one of the bacterial groups attained dominance for the others to be correspondingly diminished, but at each temperature the relative proportions of the groups varied from one experiment to another as if they were due to differences in the inoculum or the conditions in the silage. Nilsson (1956) showed that on agar some silage bacteria can suppress the growth of others by means of antibiotic products. In the present experiments each bacterial group showed in one or other silage that it could multiply side-by-side with any other group, thus suggesting unimportance to antibiotics. Apart from the differential effects of temperature, few instances were detected of one group continuing to increase when the others were static or declining, which shows that inter-group competition during the multiplication phase was not strongly selective. This does not imply that in an unstable silage a renewed growth cannot occur during succeeding months. Evidence on the time of appearance of fermentation products obtained by Gneist (1937), van Beynum \& Pette (1939), Irvin, Langston \& Gordon (1956), Nilsson, Tóth \& Rydin (1956), Rydin, Nilsson \& Tóth (1956), and others, indicates that Clostridium and Propionibacterium spp. may initiate growth at a later stage if conditions are favourable; and Kroulik, Burkey, Gordon, Wiseman \& Melin (1955) have shown a secondary increase of pediococci after several weeks. In the present work attention was purposely focused on the first week in view of some preliminary experiments which indicated that events in the early stages can have a dominating influence on the outcome of the whole fermentation.

\section{Changes in $\mathrm{pH}$ value}

The $\mathrm{pH}$ values of the grass and silage macerates are shown in Fig. 2. It will be seen that in several instances much acid must have been formed after bacteria of all the main groups had reached the phase of falling viable count. In each experiment except no. 10 the decreases in $\mathrm{pH}$ value were most rapid at $40^{\circ}$ and slowest at $22^{\circ}$; the curves tended to approach each other with time; the final values were in no instance lower than 4.3. The silage in Expt. 10 differed in showing an active acid formation at the two lower temperatures, the curves for $30^{\circ}$ and $40^{\circ}$ being nearly identical; the final $\mathrm{pH}$ value at each of the three temperatures was lower than in the other experiments. Bacteriologically, the special features of the silage in Expt. 10 were the rapidity of the growth, the density of the populations attained, and the notable multiplication of 

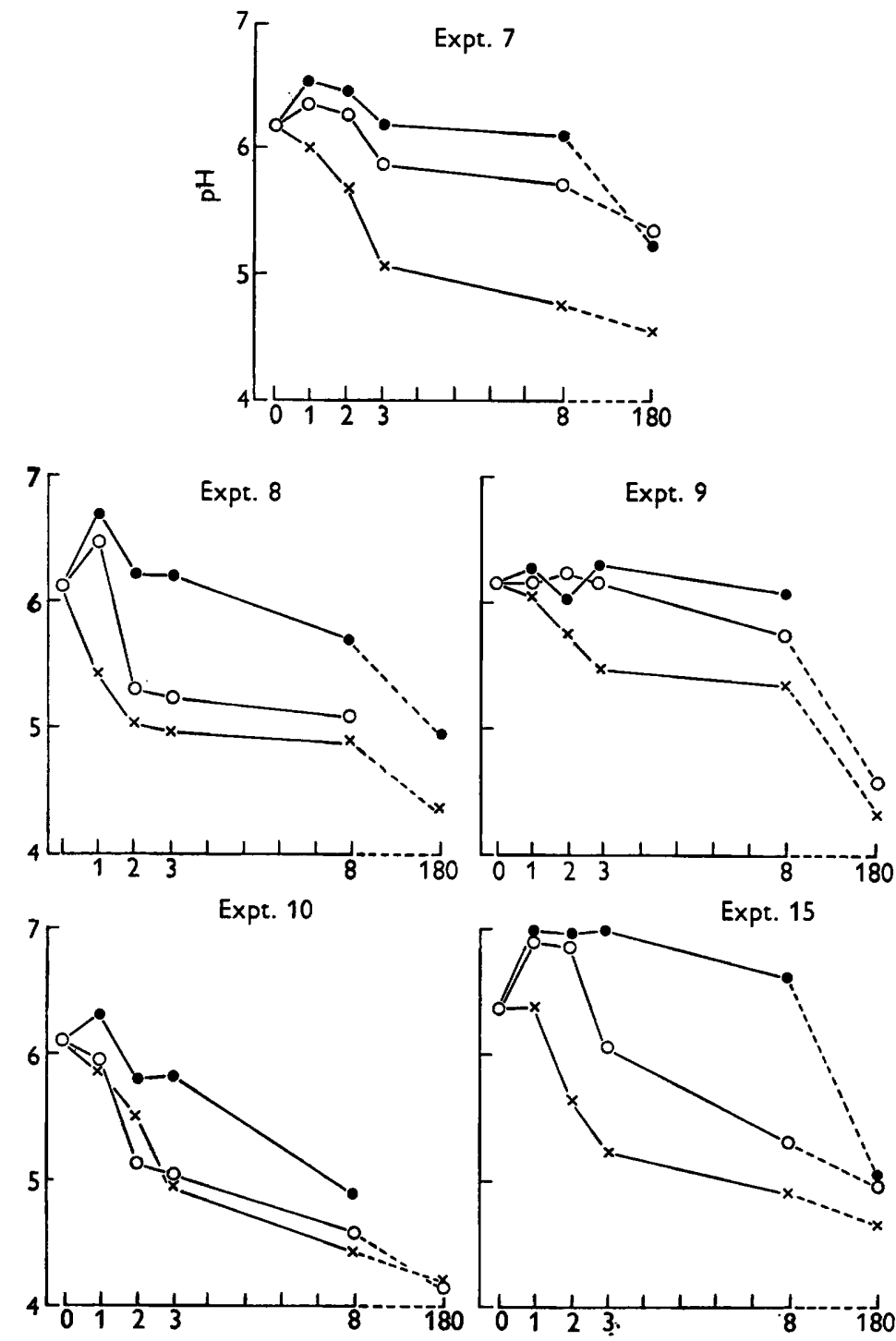

Expt. 15

$$
\text { Age of silage (days) }
$$

Fig. 2. The pH values of silage macerates. Silage made at $22^{\circ}$, $30^{\circ}, 0-0 ; 40^{\circ}, x-x$.

lactobacilli. In view of the exceptional acid-producing powers of lactobacilli it seems likely that they were at least the immediate cause of the active acidifieation in this silage. It will be noted that in Expt. 9 the count of lactobacilli reached $220 \times 10^{6} / \mathrm{g}$. Although apparently a substantial concentration of organisms, this figure is well below the maximum found in Expt. 10. It was evidently inadequate for rapid acid formation, at all events under the conditions provided by the grass in Expt. 9. 


\section{DISCUSSION}

A feature of silage made from living herbage is its complexity. Diverse bacteria develop on plant materials which vary in character; the bacteria and the plant cells both produce chemical changes which are certain to have complex results. There are, consequently, obstacles to the identification of factors which determine the events. In the following discussion an attempt will be made to isolate some of the relationships. In the interests of clarity they will be discussed under five headings.

Factors which limit the bacterial growth. Acid formation has been recognized as a dominant factor in the control of bacterial activity in silage. The importance of acids is certainly well founded, yet in the present experiments growth was frequently arrested when, as the $\mathrm{pH}$ values show, little acid could have been formed. In the silage made from each specimen of grass it was generally found that the lower the temperature the higher was the $\mathrm{pH}$ value when the peak viable count of each bacterial group was obtained. It may therefore be concluded that the accumulation of acids was not the only factor responsible for the cessation of growth.

The simplest hypothesis is that bacterial multiplication was limited chiefly by the food supply. If this were the mechanism it would account for the finding that diverse types of bacteria stop growing at about the same time. Of the bacterial groups involved, the Gram-negative rods have the simplest nutrient requirements. It could therefore be inferred that in the specimens of herbage used, sugars, the chief sources of energy for anaerobic growth, were most frequently the limiting nutrilites. The finding in these experiments that the period of growth at $40^{\circ}$ was similar to or longer than at $30^{\circ}$ indicates that during the first week there was a more continuous supply of food material at the higher temperature.

The influence of temperature on the bacterial populations. The relation of the viable to the total bacterial counts in these experiments is unknown. In the light of the findings of Jordan \& Jacobs (1947) it could be expected that the degree to which the viable counts underestimated the total counts was greatest for the silage at $40^{\circ}$ and smallest for the silage at $22^{\circ}$, and that this would apply both during and after the phase of active growth. Whatever the limitations of the viable counts, some of the methods employed could prove the presence of various bacterial groups and hence give an indication of the extent of their development. The outstanding qualitative effects of the temperatures employed were the restraint of the Gram-negative organisms at $40^{\circ}$ and of the spore formers, both the aerobic and the anaerobic, at $\mathbf{2 2}^{\circ}$. Fig. 1, shows that the bacterial multiplication in the silage at $\mathbf{2 2}^{\circ}$ was remarkably uniform, apart from rate, in the five experiments. On the other hand, the viable counts and the composition of the populations in the silage at $40^{\circ}$ showed much variation. The evidence obtained suggests that a differential effect of the higher temperature, operating on somewhat diverse populations, may explain much of the variability at $40^{\circ}$.

Herbage as a source of silage organisms. The strict aerobes, which were a 
vast majority of the bacteria on the fresh grass, quickly perished after the laboratory silos were closed. In farm silage these organisms would have more opportunities of securing oxygen, yet they could not be expected to have much action in properly made silage. Their total respiratory activity and heat production are probably negligible in comparison with those of the much greater mass of plant material.

Bacteria capable of growth in anaerobic silage were shown to vary in rate of occurrence on the specimens of fresh grass. Their subsequent development in the silage provided a strong indication that the representation of a bacterial group on the herbage is one of the factors which determine the success of that group in competition with others after ensilage. Evidence of this relationship was given more especially by the lactobacilli, a group which could be enumerated when heavily outnumbered. Only one specimen of grass, that used in Expt. 10, carried more than a very thin seeding with these organisms. The count of Lactobacillus on that grass, although it amounted to only about 1 in 20,000 of the total herbage bacteria, was unusually high as is shown by Stirling's (1953) results. It was associated with an exceptionally early and extensive multiplication of lactobacilli in the silage. These observations suggest that the relationship of the original seeding with lactobacilli to their growth in silage is one that deserves further exploration.

The examinations of the silage gave indirectly some information about the occurrence on grass of certain relevant organisms. Thus, the results of Expt. 8 make it virtually certain that lactobacilli were absent in that instance from several of the $50 \mathrm{~g}$. quantities of the grass ensiled. The work on pure cultures of Lactobacillus showed (1) that the species which multiplied in the silage varied from one experiment to another, and (2) that in every experiment, including no. 8, two or more species developed. The clostridia showed similar variations although some species possibly occurred more constantly. All this evidence leads to the conclusion that irregular chance contamination plays a large part in determining the occurrence on herbage of the typical silage bacteria. A high count presumably signifies that the organisms had proliferated on the aerial parts of the growing plant.

The influence of the properties of the herbage. In the silage made from the five specimens of grass the bacterial development varied in rate and in the concentration of viable organisms reached. The rapid and extensive growth in Expt. 10 contrasts with the delayed and restricted multiplication in Expt. 15. The variations do not show a simple relationship to the types of bacteria that were found to have multiplied. It may therefore be concluded that the specimens of herbage differed in their suitability for supporting bacterial growth. In the early stages of the silage fermentation the bacterial proliferation is believed to occur only on the plant surfaces (Ruschmann, 1939). If that be true, juice derived from the plant tissues is the medium in which growth will occur. The rate at which it is liberated and its composition are known to vary, and could be presumed to be the factors responsible for the differences in bacterial activity.

The rate of change in $\mathrm{pH}$ value also differed from one experiment to another. 
The presence of specific organisms does not appear to account for all the differences. Neither does a variation in the initial buffering capacity of the grass since the $\mathrm{pH}$ values after 6 months do not correspond with the earlier rates. An explanation which suggests itself is that acid formation is limited by the supply of sugars at the sites of bacterial growth. On this view, in Expt. 9 the feeble acid production up to the eighth day and the considerable fall in pH value by 6 months might be attributed to a slow release of fermentable sugars. That the concentration of sugar in herbage is often insufficient to permit an adequate acidification of silage is well established. In none of the experiments here described does sugar appear to have been severely deficient, although the $\mathrm{pH}$ curves suggest that it was completely utilized in some cases. No example was included of the type of grass that yields a markedly unstable silage in which the sugars are totally consumed, the acids are destroyed and the material rots.

The accumulation of acid in relation to temperature. With the exception of Expt. 10, where lactobacilli appear to have had a dominating influence, the $\mathrm{pH}$ data show no simple relation to the bacteriological findings. If decreases in the $\mathrm{pH}$ value of silage are due to the production of fermentation acids, and the available evidence indicates that this is so, it seems necessary to assume that during the first week acids were formed by bacteria which had ceased to grow or had lost their viability. Investigations of lactic acid bacteria in other media, for example those of Rogers \& Whittier (1928), Longsworth \& MacInnes (1936) and Stern \& Frazier (1941), have shown that there are various conditions which arrest growth but permit fermentation to continue. Silage would not be exceptional if it provided this situation. The special feature of silage, in contrast with pure cultures in media such as broths or milk, is in the relationship of temperature to acid formation shown by the curves of Fig. 2. A pattern of the lowest $\mathrm{pH}$ values at $40^{\circ}$ and the highest at $22^{\circ}$ is sufficiently distinctive to indicate that it is characteristic of silage in which the lactic acid fermentation is not vigorous. The effects of temperature on the bacteria and on the herbage are doubtless complex. One possibility, which does not appear to have been explored, is that the rate of sugar liberation from the plant tissues may increase with rising temperature. The decreases in $\mathrm{pH}$ value between 8 days and 6 months, and the tendency for the curves to converge during this period, suggest that sugars became available for fermentation, and that there was finally some compensation for a slow acid formation in the early stages. Sugars formed by the breakdown of polysaccharides (Wylam, 1953; Harwood, 1954; de Man 1957) might be expected to have contributed to the final results. The present work did not show whether a renewed growth of lactic acid bacteria occurred in the period between eight days and six months.

The work described in this paper was carried out as part of an investigation of crop conservation sponsored by the Agricultural Research Council. The authors are indebted to Dr Anne B. Dickinson for assistance with the Gram-negative organisms. 


\section{REFERENCES}

Allen, L. A. \& Harrison, J. (1936). A comparative study of lactobacilli from grass silage and other sources. Ann. appl. Biol. 23, 546.

Allen, L. A. \& Harrison, J. (1937). Anaerobic spore-formers in grass and grass silage. Ann. appl. Biol. 24, 148.

Allen, L. A., Harrison, J., Watson, S. J. \& Ferguson, W. S. (1937). A study of the chemical and bacteriological changes occurring in grass silage. J. agric. Sci. 27, 271.

ARnaUd, C. (1940). New aspects, theoretical and practical, of forage ensilage. Mon. Bull. agric. Sci. Pract. 31, 371.

Barnett, A. J. G. (1954). Silage Fermentation. London: Butterworths Scientific Publications.

Beynum, J. van \& Pette, J. W. (1939). Die Stabilität der Gärungssilage. Z Zbl. Bakt. (Abt. 2), 99, 353.

BurRI, R. (1918). Über Versuche betreffend die bakteriologische und milchwirtschaftliche Seite der Süssgrünfutterfrage. Schreeiz. Milchztg. 44, 39. Abstr. in Zbl. Bakt. (Abt. 2), 49, 344.

Gerlach, GüNTher \& SeIDEL (1926). Einsäuerungsversuche mit grünen Lupinen und grünen Serradella. Arb. dtsch. LandwoGes. 340, 9.

GNEIST, K. (1937). Grünfuttersilierverfahren und Silofutteruntersuchungsmethoden. Landw. Versuchsw. 128, 257.

Harwood, V. D. (1954). Analytical studies on the carbohydrates of grasses and clovers. VI. Changes in the cell-wall polysaccharides during the ensilage of perennial rye-grass with a high protein and low soluble-carbohydrate content. J. Sci. Fd Agric. 5, 276.

Hoskins, J. K. (1934). Most probable numbers for evalulation of coli aerogenes tests by fermentation tube method. Publ. Hlth Rep., Wash. 49, 393.

Irvin, H. M., Langston, C. W. \& Gondon, C. H. (1956). Development of organic acids in silage. J. Dairy Sci. 39, 940.

Jordan, R. C. \& Jacobs, S. E. (1947). The effect of temperature on the growth of Bacterium coli at pH 7.0 with a constant food supply. J. gen. Microbiol. 1, 121.

KeDdie, R. M. (1951). The enumeration of lactobacilli on grass and in silage. Proc. Soc. appl. Bact. 14, 157.

KreUla, M. (1955). On the content of butyric acid and butyric acid bacteria in silage. Acta agral. fenn. 83, 238.

Kroulik, J. T., Burkey, L. A., Gordon, C. H., Wiseman, H. G. \& Melin, C. G. (1955). Microbial activities in alfalfa and orchard grass ensiled under certain conditions in experimental silos. J. Dairy Sci. 38, 263.

Kroulik, J. T., Burkey, L. A. \& Wiseman, H. G. (1955). The microbial populations of the green plant and of the cut forage prior to ensiling. J. Dairy Sci. 38, 256.

Longsworth, L. G. \& Macrnnes, D. A. (1936). Bacterial growth at constant pH. Apparent oxidation-reduction potential, acid production, and population studies of Lactobacillus acidophilus under anaerobic conditions. J. Bact. 32, 567.

Mack, E. (1936). Untersuchungen über Bacterium herbicola. Zbl. Bakt. (Abt. 2), 95, 218.

McClung, L. S., McCoy, E. \& Fred, E. B. (1935). Studies on anaerobic bacteria. II. Further extensive uses of the vegetable tissue anaerobic system. $\mathrm{Zbl}$. Bakt. (Abt. 2), 91, 225.

DE MAN, J. C. (1957). The fermentation of cell wall substances in grass silage and in potato pulp. Leeurenhoek ned. Tijdschr. 23, 87.

Nirsson, G. \& Nilsson, P. E. (1956). The microflora on the surface of some fodder plants at different stages of maturity. Arch. Mikrobiol. 24, 412. 
Nirsson, G., Nilsson, P. E. \& Abrahamson, A. (1956). Origin of spores of anaerobic microorganisms in milk. Arch. Mikrobiol. 25, 1.

Nilsson, P. E. (1956). Silage studies III: Some characteristics of the silage microflora. Arch. Mikrobiol. 24, 396.

Nilsson, R., Tóth, L. \& Rydin, G. (1956). Silage studies I: Studies on fermentation processes in silage. The role of temperature. Arch. Mikrobiol. 23, 366.

OrLa-Jensen, S. (1947). On the identification of lactic acid bacteria, especially in silages. Rep. Proc. IV. int. Congr. Microbiol. Copenhagen, p. 503.

Orla-Jensen, S., Orla-Jensen, A. D. \& KJaer, A. (1947). On the ensiling of lucerne by means of lactic acid fermentation. Leeuwenhoek ned. Tijdschr. 12, 97.

Roessler, W. G. \& McClung, L. S. (1943). Suggested method for use of vanillin as a test reagent for indole and skatole production by bacteria. J. Bact. 45, 413 .

Rogers, L. A. \& WhitTier, E. O. (1928). Limiting factors in the lactic fermentation. J. Bact. 16, 211.

Rosenberger, R. F. (1951). The development of methods for the study of obligate anaerobes in silage. Proc. Soc. appl. Bact. 14, 161.

Rosenberger, R. F. (1956). The isolation and cultivation of obligate anaerobes from silage. J. appl. Bact. 19, 173.

Ruschmann, G. (1939). Die wissenschaftlichen Grundlagen der Gärfutterbereitung. Landw. Jb. 88, 135.

RuschmanN, G. \& Harder, L. (1931). Vorkommen von Buttersäurebakterien im Silofutter und ihre Bedeutung. Zbl. Bakt. (Abt. 2), 83, 325.

RuschmanN, G. \& КосH, R. (1930). Untersuchungen über den Nachweis und die Verbreitung der Milchsäurebakterien auf den zur Einsäuerung gelangenden Grünfutterpflanzen. Zbl. Bakt. (Abt. 2), 80, 1.

Ryorn, C., Nrlsson, R. \& Tóth, L. (1956). Silage studies II: Studies on fermentation processes in silage. The effect of various carbohydrates as supplements. Arch. Mikrobiol. 23, 376.

Scheunert, A. \& Schieblich, M. (1926). Die bakteriellen Vorgänge bei der Grünfutterkonservierung. Arb. dtsch. LandwGes. 340, 145.

Stern, R. M. \& Frazier, W. C. (1941). Physiological characteristics of lactic acid bacteria near the maximum growth temperature. I. Growth and acid production. J. Bact. 42, 479.

Strirling, A. C. (1951). Bacterial changes in experimental laboratory silage. Proc. Soc. appl. Bact. 14, 151.

Stirling, A. C. (1953). Lactobacilli and silage-making. Proc. Soc. appl. Bact. 16, 27.

Watson, S. J. (1939). The Science and Practice of conservation: Grass and Forage Crops. London: Fertiliser and Feeding Stuffs Journal.

Wylam, C. B. (1953). Analytical studies on the carbohydrates of grasses and clovers. III. Carbohydrate breakdown during wilting and ensilage. J. Sci. Fd Agric.4, 527. 